\title{
Introduction to Application of Rubber Tapping Technology and Its Impact on Production in Mekar Tani Group, Sari Laba Jahe Village, Deli Serdang Regency
}

\author{
Sumihar Hutapea, Ellen Panggabean, Rizal Azis, Tumpal HS Siregar, Suswati \\ Faculty of Agriculture, University of Medan Area, Indonesia \\ sumihutapea@gmail.com
}

\begin{abstract}
The increase of rubber production can be done by introducing tapping technology for rubber farmers, when rubber prices are low. The facts showed that smallholder rubber production is still low, in the range of 600-800 kg of dry rubber / ha / year. Tapping practiced by rubber farmers is generally not based on tapping technology, which is integrated in the aspects of plants, tapping planning and management, the use of stimulants, and a number of other technical aspects. To increase smallholder rubber production, rubber tapping technology was introduced to Mekar Tani Groups in Sari Laba Jahe Village, Sibiru Biru District, Deli Serdang Regency (North Sumatra). The results of the introduction in the form of stimulant application showed that a month after applying the stimulant, the increase in production averaged $60.65 \%$. If production without applying the stimulant was $0.18 \mathrm{~kg} /$ tree, then after applying the stimulant $0.28 \mathrm{~kg} /$ tree was obtain. The results of this study within a month were still continuing to observe other aspects such as the quality of rubber produced due to the application of stimulants, as well as farmers' income.
\end{abstract}

Keywords: production; tapping technology; rubber farmers.

\section{Introduction}

In the management of rubber plantations, the aspect of tapping by slicing the skin so that the sap dripping as production is a major component. In other words, tapping done for more than 20 years on plants requires an approach based on agronomic aspects, engineering aspects, and planning aspects and crop management. These things become a priority so that in addition to obtain the sustainable production, high production (in the form of $\mathrm{g} /$ tapping / plant) is also produced. In short, by planting superior clones that do not accompany the aforementioned aspects, rubber production remains low due to the absence of integrated tapping technology (tapping system, tapping frequency, the use of appropriate tools, the use of stimulants, etc.).

The results of the application of tapping technology which includes the application of stimulants and tapping combined with tapping 1 / 4S upward in the upper tapping area with 1/2S downward in the lower tapping field in a large number of plantation company's results in a significant increase in production. Ideally, tapping with this system is done with a tapping frequency of 1 x 3 days. However, for rubber farmers, the frequency cannot be changed, bearing in mind that there are other activities that have been periodically carried out. This also relates to the arrival of buyers who have also been periodic.

In addition to applying the right concentration of stimulants (Siagian and Siregar, 2011), increased production must also be based on the regularity of tapped fields. Siregar and Suhendry (2009) concluded that the tapping in the planned tapping field would be advantageous in the long run because the lower tapping field could be tapped for 12 years (B0-1 and B0-2), then the recovered skin on both tapping fields could be combined with the tapping of the top tapping fields (H0-1 and H0-2) for 12-15 years, which then ends in free tapping for 2-4 years. Thus, tapping can be done at least 25 years (Fu et.al, 2007).

The facts show that rubber farmers have not been equipped with this understanding and skills, even ignoring the tapping system as an integrated system. In most smallholder rubber plantations (hevea small holders), these bases are often neglected, so that community rubber production is only in the range of $600-8000 \mathrm{~kg}$ of dry rubber / ha / year, still below production 
standards in the range of 1200 - $1500 \mathrm{~kg}$ of dry rubber / ha /year. This is the background of the importance of the introduction of integrated rubber tapping technology, as an important part of efforts to increase production. This introduction is considered a priority, given the price of rubber that has not increased, which is in the range of Rp.6.500 - Rp.8.5000 / kg wet. In short, without any effort to increase production, rubber farmers do not get adequate income from managed rubber plantations (Barkley and Parkley, 2013).

On the basis of the need for knowledge and application of rubber tapping as an integrated technological system, the introduction of rubber tapping technology was carried out in one farmer group, which manages its rubber plants with multiple cropping patterns. This paper reports on the results obtained from the introduction of rubber tapping technology in the form of applying a stimulant, as an effort to increase the production of rubber farmers.

\section{Materials and Methods}

The research in the form of this introduction of technology was carried out at Mekar Tani Groups, located in Sari Laba Jahe Villages, Sibiru Biru District, Deli Serdang Regency (North Sumatra). A total of 20 rubber farmers were included in this activity, which manages rubber plants in multiple cropping plantations that is rubber is managed on land that was also planted with a number of annual crops such as durian, duku, and sugar palm. The tapping technology introduced was in the field of tapping B0-1, as presented in Table 1.

Table 1. Introduction of Tapping Technology

\begin{tabular}{|l|l|l|l|}
\hline No & Component & $\begin{array}{l}\text { Pre-introduction } \\
\text { tapping (Pra I) }\end{array}$ & Tapping introduced (Pasca I) \\
\hline 1 & Tapping direction & Irregular & Start top left to bottom right \\
\hline 2 & Tapping field & Unplanned & Starting from B0-1 \\
\hline 3 & Stimulants & Never & $\begin{array}{l}\text { 2\%, smeared after 4-5 times tapping, } \\
\text { after first pulling the scrap (sap that } \\
\text { covers the tapping groove) }\end{array}$ \\
\hline 4 & Tapping combination & Never & $\begin{array}{l}\text { B0-1 combined tapping with 1 / 4S } \\
\text { upward using a special knife. } \\
\text { Combination is done 2- 4 times a month }\end{array}$ \\
\hline 5 & Standard tapping slices & Never considered & Only 1.25 mm thick each time tapping \\
\hline 6 & Depth of tapping & Never considered & Prevent wounded cambium \\
\hline
\end{tabular}

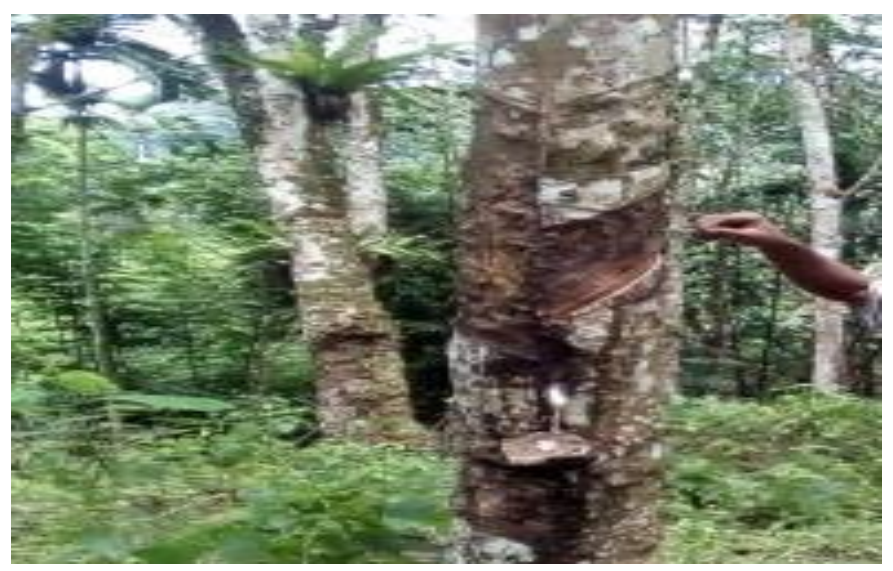

Figure 1. Plant conditions due to tapping without technology and an ideal tapping system 


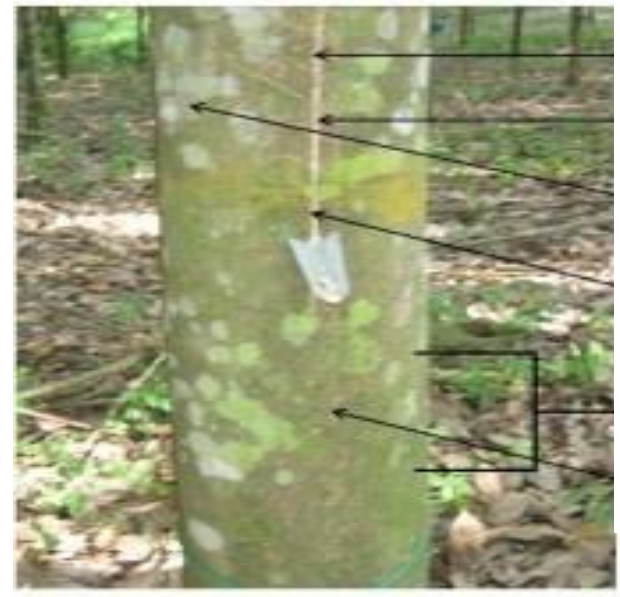

Combine tapping with $1 / 4 \mathrm{H} 0-1$ using a special knife

In tapping: $1.5 \mathrm{~mm}$ (prevent cambium injury)

Tapping direction: from top left to bottom right

Apply stimulants after scrap is pulled

Start tapping at B0-1 (lower, left tapping field

Skin slices of each tapping: 1, $25 \mathrm{~mm}$

Figure 2. Introduced tapping technology

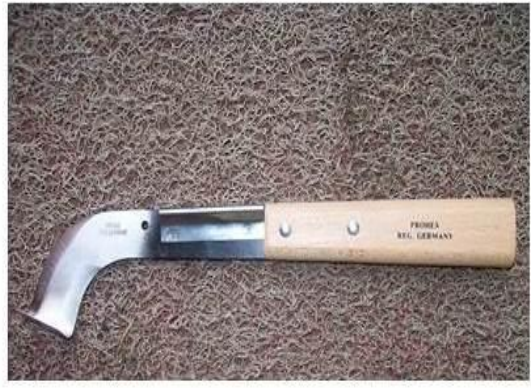

Taping knife for the lower tapping field $(1 / 2 \mathrm{~S})$

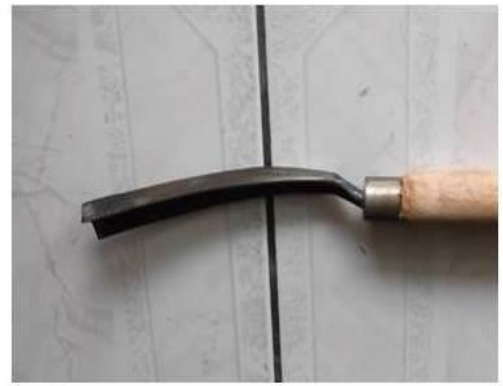

Special tapping knife for the top tapping field

Figure 3. Specific tapping knives for top tapping fields which was introduced

In its application, training was first carried out in the plantation of the member of farmer group for 4 times, accompanied by a visit to Sungei Putih - Rubber Research Center. To find out the impact on production from the introduction of this technology, 16 farmers were chosen to separate the plants that were still being tapped before the introduction of technology (Pra I) and post technology introduction. Production is recorded every week, while the frequency of wiretapping continues to be done 1 x 2 days. All these activities were carried out starting in June 2019 and are continuing to discuss barriers and possible development of more specific training (such as post-harvest handling, formation of cooperatives, etc.).

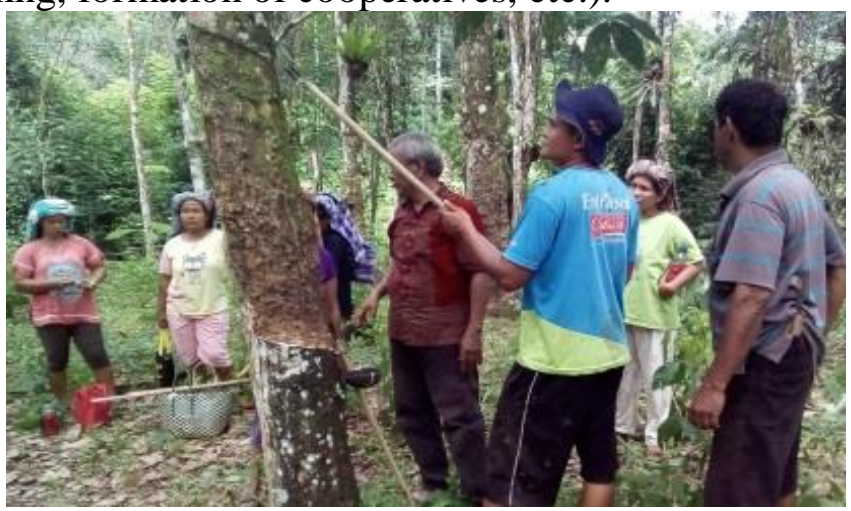

Figure 4. Tapping technology training before applied to their respective gardens 


\section{Result and Discussion}

In other words, the application of stimulants as a component of tapping technology can increase production. In farmer number 14 , the increase in production $<20 \%$ is due to the tapping having just begun, that is the tree that was first opened for tapping.

Table 2. Impact of Introduction of Tapping Technology by Applying Stimulants to Production

\begin{tabular}{|c|c|c|c|c|c|c|c|c|}
\hline \multirow{2}{*}{ No } & \multirow{2}{*}{ Farmer's name } & \multicolumn{2}{|c|}{$\begin{array}{l}\text { Production of } 10 \\
\text { trees }(\mathrm{kg})\end{array}$} & \multirow{2}{*}{$\begin{array}{l}\text { The } \\
\text { amount of } \\
\text { stimulant } \\
\text { application } \\
(\text { times)*) }\end{array}$} & \multicolumn{2}{|c|}{$\begin{array}{l}\text { Per-tree } \\
\text { production (kg) }\end{array}$} & \multirow{2}{*}{$\begin{array}{l}\text { Increase } \\
(\%)\end{array}$} & \multirow{2}{*}{ Information } \\
\hline & & Pra I & Pasca I & & Pra I & Pasca I & & \\
\hline \multirow{2}{*}{1} & \multirow{2}{*}{ Hera br Sinuraya } & 2,9 & 3,4 & \multirow{2}{*}{1} & 0,29 & 0,34 & 85,29 & \\
\hline & & 2,8 & 3,2 & & 0,28 & 0,32 & 87,50 & \\
\hline \multirow{2}{*}{2} & Wasta br & 2,5 & 3,4 & \multirow{2}{*}{2} & 0,25 & 0,34 & 73,53 & \\
\hline & Sembiring & 2,3 & 3,2 & & 0,23 & 0,32 & 71,88 & \\
\hline 3 & Irwan PA & 2 & 2,7 & 1 & 0,2 & 0,27 & 74,07 & \\
\hline 4 & Adil Tarigan & 1,3 & 2,4 & 1 & 0,13 & 0,24 & 54,17 & \\
\hline \multirow{3}{*}{5} & \multirow{3}{*}{ Titom Tarigan } & 1,8 & 2,8 & \multirow{3}{*}{2} & 0,18 & 0,28 & 64,29 & \\
\hline & & 1,3 & 2,8 & & 0,13 & 0,28 & 46,43 & \\
\hline & & 1,4 & 2,2 & & 0,14 & 0,22 & 63,64 & \\
\hline \multirow{3}{*}{6} & \multirow{3}{*}{ Juni Tarigan } & 1 & 1,8 & \multirow{3}{*}{2} & 0,1 & 0,18 & 55,56 & \multirow{3}{*}{$\begin{array}{l}\text { Rain, during } \\
\text { the second } \\
\text { basting }\end{array}$} \\
\hline & & 0,9 & 2 & & 0,09 & 0,2 & 45,00 & \\
\hline & & 1 & 1,8 & & 0,1 & 0,18 & 55,56 & \\
\hline 7 & Antoni Tarigan & 1,6 & 2,6 & 1 & 0,16 & 0,26 & 61,54 & \\
\hline \multirow{2}{*}{8} & \multirow{2}{*}{ Iwan Tarigan } & 3 & 5 & \multirow{2}{*}{2} & 0,3 & 0,5 & 60,00 & \\
\hline & & 2,5 & 4 & & 0,25 & 0,4 & 62,50 & \\
\hline \multirow{2}{*}{9} & \multirow{2}{*}{ Nunus Sinuraya } & 2,8 & 4 & \multirow{2}{*}{1} & 0,28 & 0,4 & 70,00 & \\
\hline & & 2,8 & 3,6 & & 0,28 & 0,36 & 77,78 & \\
\hline \multirow{3}{*}{10} & & 1,7 & 2,5 & & 0,17 & 0,25 & 68,00 & Retired \\
\hline & Jumali & 1,6 & 2,8 & 1 & 0,16 & 0,28 & 57,14 & plantation \\
\hline & & 1,6 & 3 & & 0,16 & 0,3 & 53,33 & \\
\hline & & 2 & 3 & & 0,2 & 0,3 & 66,67 & \\
\hline & Kaperas br & & & 1 & & & & \\
\hline 11 & Tarigan & 2 & 3 & & 0,2 & 0,3 & 66,67 & \\
\hline & & 2 & 3 & & 0,2 & 0,3 & 66,67 & \\
\hline 12 & Benata Tariogn & 2,2 & 3 & 2 & 0,22 & 0,3 & 73,33 & \\
\hline 12 & Benata larigan & 2 & 2,8 & 2 & 0,2 & 0,28 & 71,43 & \\
\hline 13 & Eliecer & 1,5 & 2,6 & 2 & 0,15 & 0,26 & 57,69 & \\
\hline 13 & Elleser & 1,2 & 2,2 & 2 & 0,12 & 0,22 & 54,55 & \\
\hline & & 0,23 & 1,2 & & 0,023 & 0,12 & 19,17 & \\
\hline 14 & Adi Putra Barus & 0,21 & 1,5 & 1 & 0,021 & 0,15 & 14,00 & Just tap open \\
\hline & & 1,2 & 2,5 & & 0,12 & 0,25 & 48,00 & \\
\hline 15 & & 0,26 & 1,4 & 1 & 0,026 & 0,14 & 18,57 & \\
\hline 15 & verandes S & 1 & 1,5 & 1 & 0,1 & 0,15 & 66,67 & \\
\hline & Pendi & 2,7 & 3,6 & 1 & 0,27 & 0,36 & 75,00 & \\
\hline 16 & Peranginangin & 2,6 & 3,4 & & 0,26 & 0,34 & 76,47 & \\
\hline & Average & 1,76 & 1,40 & 2,76 & 0,18 & 0,28 & 60,65 & \\
\hline
\end{tabular}

*) In the period of 2 July 2019 to 2 August 2019. The amount of stimulant application depends on other farmers' activities, so that the frequency and time of its application cannot be determined simultaneously. But the principle of basting is done every 4-5 times of tapping. Tapping in 1 week is done 3 times, or 12 times a month. Ideally, the application of stimulants is done a maximum of 4 times a month. The data 
above is the result of a trial in which production data is recorded post stimulant in 10 trees which are smeared. Pre I = before application of stimulants Post I = after application of stimulants.

For newly tapped trees, the application of stimulants is not recommended. Likewise, the application of stimulant if within $<2$ hours later it rains, it will affect the damage of latex that flows so that it cannot freeze, as experienced by farmers number 6 . Whereas farmers number 10 , data (not presented) shows the number of trees tapped an average of 300 trees / tapping day. This shows that the factor of the number of trees being tapped every day is also a component of tapping technology. In other words, high skills make an increase in the number of trees tapped per tapping day (Yujieet.al, 2012). Other factors that must also be considered are the type of planting material (seeds or clonal), spacing, cleanliness of spaces, quality and type of tapping knives, tapping frequency, besides the stimulant component (Siregar, et.al, 2008).

Table 1 proves that one component of tapping technology, namely the application of stimulants, has been able to increase production by an average of $60.65 \%$, or increase from 0.18 $\mathrm{kg} /$ tree (Pra I) to $0.28 \mathrm{~kg} /$ tree (Pasca I).

The results obtained are one component that can significantly increase the income of rubber farmers. When rubber prices continue to be low, increasing production is one of the efforts to increase the income (Siregar and Siagian, 2016).

This research is still being conducted to determine the impact on the quality of the rubber produced, including levels of impurities and levels of dry rubber from the application of stimulants. Overall tapping technology is projected to increase production and quality of smallholder rubber.

\section{Conclusion}

From the observations of a month after the introduction of tapping technology in the form of stimulants application for 1-2 times a month on rubber farmer of Mekar Tani Group concluded that an increase in production an average of $60.65 \%$. The average production before application is $0.18 \mathrm{~kg} /$ tree, increased to $0.28 \mathrm{~kg} /$ tree. The number of tapped trees / tapping days is an influential component, as a skill implication, besides the age of the tree. This activity continues to observe other factors such as the income of rubber farmers and the quality of rubber produced due to the application of stimulants.

\section{Acknowledgement}

Thank you to Directorate of Research and Community Service to the Community, Directorate General of Higher Education, Ministry of Research and Education / Higher Education, for its financial support through the PKM Grant with Decree Number T / 140 / E3 / RA.00 / 2019 dated February 25, 2019 and Agreement Letter for Implementing Partnership Programs at the University of Medan Area Community Number: 571 / LP2M / 04.6 / VII / 2019 dated July 8, 2019.

The author would like to thank all members of Mekar Tani Groups, Sari Laba Jahe Village, Sibiru Biru District, Deli Serdang Regency (North Sumatra) who participated in this activity, specifically to Mr. Setia Budi Barus as the head of the farmer group. Acknowledgments were also conveyed to the leadership of UMA, who supported the administration aspect. Acknowledgments were also conveyed to Research Center Service Unit of Sungei Putih - Rubber Research Center in a comparative study of farmer groups. 


\section{References}

Barkley, A and P.W. Barkley. (2013). Principles of Agricultural Economics.Cenveo Publisher Services.351p.

Fu, Y., Guo H., Chen, A., Cui, J. (2007). Rubber development by smallholder farmers in XishuangbannaYunnan, China, a case study from Daka and Baka.24p.

Prasanna, W.R.A.C., V.H.L.Rodrigo D.C. Abeysinghe and K. V. V. S. Kudaligama. (2010). Stimulant levels to be used with two low intensity harvesting (LIH) systems of rubber under wet and intermediate zones of Sri Lanka. Proceedings of the 15th International Forestry and Environment Symposium. p.265-272.

Siregar, Tumpal H.S and I.Suhendry. (2009).Fungsi, manfaat dan pelaksanaan tap inspeksi pada perkebunan karet. Buku saku.Balai Penelitian Sungei Putih - Pusat Penelitian Karet.26p.

Siregar, T.H.S, Junaidi, Sumarmadji, Nurhawaty Siagian, and Karyudi. (2008). Perkembangan Penerapan Rekomendasi Sistem Eksploitasi Tanaman Karet di Perusahaan Besar Negara. Pros. Lok. Nas. Agribisnis Karet 2008. Yogyakarta, 20-21 Agustus 2008.

Siagian, N and Tumpal HS Siregar. (2011). Pemeriksaan kualitas sadapan untuk mendukung produktivitas yang tinggi dan berkelanjutan. Workshop Penggunaan Klon Unggul Baru dan Sistem Eksploitasi Tanaman Karet yang Tepat Dalam Menghadapi Peningkatan Harga Karet Alam Dunia. Balai Penelitian Sungei Putih. Pusat Penelitian Karet.14p.

Siregar, T.H.S and N. Siagian. (2016). Hasil evaluasi tanaman menghasilkan PT. Mapoli Raya.Balai Penelitian Sungei Putih.5p.

Takuathung. (2006). Rubber Plantations in Southern Thailand: management and social and economic functions.28p. 